\title{
Chinese Left-Wing Literature in the Vision of an American Left-wing Writer*
}

\author{
HUANG Jing \\ Southwest University, Chongqing, China
}

\begin{abstract}
As one with great fame of writing China and Chinese people in war time, Anna Louise Strong, has the experience of communicating with Chinese left-wing writers, viewing their dramas works and reading their novels. From her perspective, Chinese left-wing literature was featured by its revolution and popularity; Chinese left-wing writers were busy with creating different genres to get every Chinese’s involvement in the anti-Japanese war in 1930s and participation in the construction of new China in 1940s. Hence, they were multifarious in their identity because they cared more than literature in a turbulent time. From what she presented, China, as a cultural otherness, was the existent utopia that fulfilled her radical political dream of communism.
\end{abstract}

Keywords: left-wing, revolution and popularity, multifarious identity, utopia

\section{Introduction}

Anna Louise Strong (1885-1970), an outstanding left-wing American journalist and author, wrote thirty-three books and numerous articles. She was best known for her support for communist movements in Russian and China. After obtained a Ph.D. in philosophy from the University of Chicago in 1908, she worked for a Child Welfare Program, a federal agency established by President William Howard Taft. Defeated in her belief that American failed to be real fair and democratic, she was gradually disappointed with the inefficiency and the high unemployment rate. She moved to Seattle, wrote for the trade-union-run Seattle Union Record, and actively encouraged the Seattle General Strike in 1919. After the internal collapse of the strike, she went to the Soviet Union to learn more about the victory of the workers in Russia. There she wrote plentiful reports on the new Soviet and became one of the best-known reporters. However, she was still unsatisfied for not experiencing the whole process of a great commnunist revolution. To fulfill her dream of watching a revolution, her attention was thus easily turned to China. She chose China as the ideal place to witness how Chinese people, especially lower class workers and peasants, were fighting for their own right and in order to drive out the invasion of imperialist power. She visited China six times from 1925 onward, interviewing "different places and people” and casting her accounts favorably to Chinese revolution. In her reportage book One Fifth of Mankind: China Fights for Freedom (1938), she dedicated a large portion to the comment of Chinese drama and other forms of literature by

\footnotetext{
* Acknowledgements: Supported by the Research Funds of Chongqing Cultivation Project (2014PY39) and the Fundamental Research Funds for the Central Universities (SWU1309391).

Huang Jing, Ph.D., lecturer, College of International Studies/ College of Arts and Literature, Southwest University.
} 
some famous Chinese leftwing writers, which as a whole displayed the cultural landscape of Chinese left-wing literature movement in 1930s and 1940s. She mentioned different genres of arts: "Big Drum Singing”, "Wall Posters”, "Poems to be declaimed”, “Yanko Dance”, and “Novels”, among which Chinese drama was the major genre. What is more is that she got the chance to interview many Chinese left-wing writers, Ting ling, Hu Lan-shih, Cheng Hsueh-chao, Tien Han, Zhou Li-bo, etc.. What on earth did she see the other since they were both on the left but with the different cultural background? What was the real landscape of Chinese left-wing writers? Why did Strong present them in that way?

\section{Revolution and Popularity: The Character of Chinese Left-Wing Literature}

Chinese new literature has aroused great interests of many foreign writers. Strong was one of the first generation of westerners who came to China to witness China's great changes evolving from the old to the new. New literature differed from the old or traditional literature as one of the biggest achievement of the May Fourth Movement in 1919. This literature underwent a complete transformation not only in language, but also in theme and genres. Chinese left-wing literature was the main trend of this literary revolution. Edgar Snow, the author of Red Star Over China (1937), edited a collection of modern Chinese short stories (in English), Living China. In the preface of the book, he declared Chinese left-wing literature was to resist to the reactionary ruling of KMT (Snow, 1983, p. 4). His ex-wife, Helen Foster, another American author, shared his opinion a lot, also approved the political function of the literature, and thought Chinese new literature altered with the political movements. Strong admitted the political function the same but differed from their idea in thinking that Chinese left-wing literature was closely related to the war but not the civil war, working for the independence for the country, and enlightening people's awareness of fighting against Japanese invaders. In terms of Strong, the Chinese literature was neither for the domestic political conflicts, nor the class conflicts, but the aim was to arouse the patriotism of the whole country to fight for the sovereign rights of the country. She wrote in her book:

When the present war began and fighting spread on a large scale through the country, more and more leading writers put their pens at the service of the war. Literature became simple and full of incident, designed to arouse the people. It dealt not so much with Japan's internationally imperialist policies but portrayed the invaders very concretely as robbers and murderers, burning houses, raping women. Its theme became "Defend your homes", rather than "Resist imperialism". It is full of heroic deeds of Chinese soldiers and of the sufferings of Chinese people. (Strong, 2006, pp. 156-57)

She conveyed this idea by citing some examples. One was “The Battle of Pinghsing Pass” displayed the soldiers' fighting life in the form of an ancient Peiping style of chanted ballads with instruments of drum and string, named “Big Drum Singing”, performed by Ting Ling group. Another was a drama performed by Shanghai troupe, “On the Banks of the Whangpoo”, which showed two coolies swam to Japanese ships at night to attach bombs. Particularly, the local play "Defense of the Village” expressed the inner struggle and hesitation of farmers who were submissive to any dominant power. It portrayed an old peasant discussing with his daughter-in-law the approach of the Japanese, whether to make peace with them or to fight against them. The old man thought Japanese might be mercy to him because of his law-abidingness. Unfortunately, the young woman and the old man were killed when Japanese and a Chinese traitor came. The old man, dying, told his son, who returned with the band of Farmer Fighters to revenge, "he had been wrong to rely on Japanese mercy and that resistance was the only way”(Strong, 2006, p. 154). The words reinforced the attitude of fighting, the only way to rescue China. 
Strong realized this and critically pointed out many other dramas possessed similar themes, i.e., anti-Japanese war was disturbing every person's life, which couldn't be avoided, therefore, massive people should take the responsibility of resisting and protecting their homeland.

Another feature of Chinese left-wing literature from Strong's presentation was the popularity. Two aspects could demonstrate it. One aspect was that literature was so immersing into people's life that Strong could encounter it in different places and in diverse forms. In her eyes, poets began to go to villages; dramatists and novelists moved to inland. In 1938, Strong came back to China and spent some time travelling with General Zhu De and the Eighth Route Army. In a tiny village in Shanxi province, she ran into two dramatic companies at the same time. One was a group of Shanghai players touring the battle-fronts and the other was the Eighth Route's own dramatic company organized by Ting Ling, a famous woman writer. On her way to Hankow, she met a group of 13 students zigzagging back and forth to put on patriotic dramas.

The most picturesque of all the actors' groups which toured the country was a troupe of twenty-four Shanghai children aged nine to nineteen. War destroyed their homes and drove them with their parents into refugee camps but they refused to stay there. (Strong, 2006, p.155)

Strong called them "Children's Dramatic Club”, and introduced that they put on nine war-time plays, all written by well-known playwrights for amateur production. The short plays of Tien Han, a leading left-wing dramatist, were so popular that teachers taught pupils in village schools. Some one-act plays were commonly copied by children in their games. These details showed that left-wing literature was transplanted into people's life, either for public enlightenment or entertainment. It changed the traditional perception of that literature or art as only being useful for the entertainment of the upper class, and got most ordinary people involved. It became the spiritual celebration of the whole nation. People with different backgrounds were united by the spread of literature. The other aspect exhibiting the theme of popularity was the reaction of the audiences or the readers. Strong especially noticed people's response when she wrote Chinese left-wing literature. She commented: "they listened breathless to the story of their own victory”, "even more applauded were the Shanghai players" (Strong, 2006, p. 152) and declared that Chinese dramas in an open-air village theater were "the best dramatic acting”. She wrote,

Under these crude conditions the two dramatic troupes put on their performances which held their audience spellbound for many hours. The sun went down and the winter stars shone on the village drama; kerosene lamps were brought to light the stage. Till after ten on a bitter January night the blue-gray soldiers stood watching, laughing, applauding. The dramas showed aspects of the war against Japan; they were portrayals of life as those soldiers knew it. (Strong, 2006, p. 152)

The crude condition—a bitter winter night, kerosene lamps, no seats, contrasted with audience's hypnotic fascination, watching, laughing, and applauding. What a harmonious picture that Strong wanted to show to her American fellows! The cruel nature and backward circumstance couldn’t prevent people enjoying their own literature. They celebrated their victories, sharing their stories of sorrows but more importantly, cheering their spirit for their strong belief in the victories of the future, which formed another contrast by the lonely hearts in the waste land of modern cities and advanced facilities in America.

However, Strong's compliments on Chinese left-wing literature were not absolute. She pointed out, "Literature became simple and full of incident” (Strong, 2006, p. 156), “some of the dramas are so extremely 
simple...” (Strong, 2006, p. 157) "Crude as are these amateur performances” (Strong, 2006,p. 156). She soon explained that the simplicity was easy for people to copy; incidental plot was designed to appeal to the audience's revolutionary spirit, and crude performances were "furnishing the vehicle" for "the best" Chinese authors' writing. Therefore, Strong was quite approval for Chinese left-wing literature’s involvement to the war and admired the intimate relationship between writers and readers.

\section{The Multifarious Identity of Chinese Left-Wing Writers}

When defining literature, Terry Eagleton denied those criteria that were widely accepted, like literariness or practical functions. Then he offered a general definition of the "literary" which is in fact historically specific. He further brought forth that

the so-called "literary canon" of the "national literature", has to be recognized as a construct, fashioned by particular people for particular reasons at a certain time. "Value" is a transitive term: It means whatever is valued by certain people in specific situations, according to particular criteria and in the light of given purposes. (Eagleton, 1996, p. 10)

It might be the similar case of understanding the so-called left-wing literature when Strong fixed her eyes on Chinese left-wing writing. Although Chinese left-wing movement was under the world trend of the radicalism, it was closely involved in the complex historical contexts of modern Chinese enlightenment, national independence, and political revolution. The movement's literary form, theme, together with its spread could not depart from the efforts dedicated by the writers, whose attitude of writing and way of living were also confined to the historical context, displaying the particular characteristics. Strong constructed the multifarious facets of Chinese left-wing writer when introducing Chinese left-wing literature.

Strong had a clear vision of the issue of war as a key factor in the changing pattern of literature, especially the centers of writing, reading, and spreading, which symbolized the birth of a new culture and literature. At the same time, those changes not only happened on literature itself, but also on writers and actors. In another word, writers were forced to cease their dream of being pure writers, as they had to survive in the war. They might be refugees, soldiers, actors, and peasants. According to Strong,

Many writers have gone to the front for active service in arousing the people; among these the most important are Ting Ling, the leading left-wing woman writer; Hsu Chen, the well-known novelist; and Chou Li-po, the essayist. Most of them are too active to spend much thought on the theory of writing. (2006, p.158)

Yet, it was this particular circumstance that allowed the emergence of particular criteria to discuss the value of left-wing literature. Indeed, Strong had unique standards to evaluate the success of a writer.

First, Chinese left-wing writers might act as a bridge to establish the communication between the peasants and the communist soldiers. Hu Lan-shih, a well-known woman writer who organized a group of Shanghai working girls in the earliest days of the war, was portrayed as a "quite, well-poised young woman, with a vivid sense of humor and superlatively straightforward and honest”(Strong, 2006, p. 166), to a typical new woman. She was outstanding not for her writing or gender charms, but for her deep understanding of the farmers. "Miss Hu herself had an almost uncannily shrewd knowledge of the Chinese farmer mind”(Strong, 2006, p. 166). With the tone of praising, Strong accounted Miss Hu's amazing events in motivating peasants to serve for the soldiers, harvest the crops, take care of the injured soldiers, reclaiming dozens of child-traitors, and halting retreating 
soldiers.

Second, Chinese left-wing writers joined the army, moved to the battle-fields to perform as soldiers. They might forget their identity as writers temporarily, and devote their time to promoting the career of anti-Japanese war. Strong was so curious about the modern Chinese literature that she interviewed Ting Ling directly. She had already sensed that the war changed the style of literature, and the writers' way of living. To enforce her confirmation, Strong quoted her interview with Ting Ling.

When I asked Ting Ling to tell me the latest tendencies in Chinese literature, she answered, “I don’t know a thing about literary tendencies; I've been six months at the front. But I have a clear opinion about the duty of the writer. He has only one task today: to help save the country. We must simply write to arouse the masses”. (Strong, 2006, p.158)

In this respect, Chinese writers were busy with their identity as writers as well as soldiers. They were no more confined to only one character but actively to play other roles. They played as actors to put on dramas, made public speeches, drew cartoons on the village walls and taught the peasants to sing, and fostered the popularization by singing songs. They regarded themselves as common soldiers, without enough food, or any transportation tool. What they cared were not pure literature creation, let alone those who insisted arts for art's sake in China's critical moment. In the interview, Ting Ling expressed the real concern of writers, "From the standpoint of art our playing is backward, but the peasants like to see us because we dramatize their own life" (Strong, 2006, p.158). "Our life, you see, is rather hard, but our audiences have smiling faces when we come, even in the midst of all this danger and death. So we are happy too.”(Strong, 2006, p. 159). Art was laid aside; the peasants' reaction was valued, even at the cost of hard life, danger, or death.

Third, Cheng Hsueh-chao, a successful writer in Strong’s eyes, was praised by Strong, "She had mastered the approach to a peasant home”(Strong, 2003, p. 75). Cheng Hsueh-chao's example vividly illustrated how the writers tended to stay in villages and live as farmers. Strong had a closely talk with her on August 1st, 1946. Through the record of their talk, Strong revealed why Chinese left-wing writers penetrated into people and how they thought of political policy working on literature. Strong emphasized that Miss Cheng was not a communist but her choice of Yenan was very wise. Miss Cheng left her silk merchant family, took part in the women's rights movement in 1925-27, and felt disillusioned for the prosecution of Jiang Kai-shek's government. Then she fled to France to enjoy free life but could not endure such freedom after seven years in France. She came back to China, went around many cities until she found real freedom in Yenan, saying "A writer's life is very satisfying here"(Strong, 2003, p. 74). She lived in a shallow cave with very simple furniture, which was entertained as "Yenan style”. She didn't care about the shabby residence as she explained to Strong that the house was better than local peasants' houses just because of a bigger window, and what she really needed was spiritual food. In addition, she volunteered to teach farmers winter classes, help the housewife cook, sweep the ground, feed the animals, and grind the millet. These details indicated how a bourgeoisie lady turned to communism and her life and spirit was totally transformed,

"I think Mao Tze-tung’s views on literature are very sound”, “Mao call us to know the people of our country, to go among them and portray their life. When we go to the villages it is a double benefit. We import some ideas of sanitation, some general enlightenment. Meanwhile we ourselves gain more intimate knowledge of our country's life. I especially need this because I spend so many years abroad. But most of our writers come from the upper class and do not know the Chinese peasant”. (Strong, 2003, p. 74) 
Writers in Yenan were spiritually satisfied because they were not blind in mind anymore. With the political guidance, they knew modern literature was not necessarily the copies from the west, or merely the heritage of the tradition. They agreed with the literary theory of Mao Tze-tung, which encouraged artists to depict the realistic life of peasants. Miss Cheng was described to show the process how she converted to believe in the Chinese communism and follow the leadership to be one successfully connected with Chinese peasants.

From the three Chinese women writers portrayed by Strong, one distinctive feature was their active change of identity, their roles played as soldiers, peasants or actors to foster the engagement of every individual to attend the independence war. It seemed that they were well organized and very clear with what they should do. Literature was the tool undertaken to serve for the public affair, the independence and liberation of the country. The guidance of Mao Tze-tung's views on literature was the answer to their highly coincident identification and action.

\section{The Real Landscape of Chinese Left-Wing Literature}

Unlike the consensus that Chinese left-wing literature was primarily affected by the Marxist proletariat literature of the USSR, Strong didn't spoke of the similarity and cautiously avoided talking about the relation. She didn't see the relationship between Chinese left-wing literature and Soviet literature. It was probably because she wanted to differentiate the two. In fact, Strong held her view towards Marxism. In her autobiography, she mentioned, the American communists was blindly follow the leadership of Moscow, which led to the total failure of American communist movement. Additionally, with the deeper understanding of USSR, she was not so approving of misdeeds of Stalin dictatorship, like the political purge, the concealing the starvation along the Volga and the miserable death of her best female friend devoting all to her work but not so much admitted by the government. As a result, China was another hope. From her visiting in 1930s, she never evaluated China with the rule of USSR as what she did in her 1920s' visiting. It was no wonder that she thought Chinese communists were independent with Mao's literary theory and Chinese left-wing literature was born and developed within its own context.

From the perspective of Strong, Chinese left-wing literature was born and urged by the war, under which left-wing writers politically turn left, took the responsibility to stand by the side of people and the country and naturally came to believe in communism and follow the leadership. From another perspective, Strong's account of Chinese left-wing literature was not only the record of facts, but a mirror clearly reflected Strong's political recognition and emotional admiration. The communist controlled place of China, especially on behalf of the hope of a new order, the most advanced social system, was a realized communist utopia that carried Strong's dream of being a typical radical contributing to such a new social system lying in freedom and democracy that Americans always pursued.

Moreover, she confirmed the specialty of Chinese left-wing literature from her failure experience in the radical movement in America. On February 6, 1919, two days before the beginning of the Seattle General Strike of 1919, she proclaimed in her famous editorial, "We are undertaking the most tremendous move ever made by labor in this country, a move which will lead - NO ONE KNOWS WHERE!”(Strong, 1919, p. 1). The strike was rising as "the iron march of labor" but then ended peacefully. She mentioned this failure in her autobiography - I Change Worlds: the Remaking of an American (1935), reflecting the fear and blindness of this radical move. 
Due to no explicit and defined guiding idea like Mao's theory in China, but only roaring radical action, the Strike went to no where, and was last tackled by the local government. That was a bravery try, but a pitiful and bitter experience for Strong. Years later, she went to China and witnessed the revolution, and finally understood China's communists could win people because they had quite a clear guidance. All Chinese left-wing writers' action and spirit were presented as well-organized and highly coincident. To her, Chinese left-wing literature was a good example to illustrate the perfect relationship between writers and readers as well as between writers and politics.

To some degree, it was an illusion that Strong constructed this harmony to fulfill her dream because she was not insightful or critical enough to see the other side of Chinese left-wing literature.The truth was that the left camp was not a monolithic whole as Strong's assumption. Writers were gathered in the name of national salvation, Chinese communists, fellow travelers, liberals, and nonparty radicals, united in the institution of Left League. Yet, they divided into several groups, mainly two camps, the Creation Society and Sun Society, both of which advocated the movement of revolutionary literature. But their understanding the connotation of "revolution" and "literature" was different, and they took different strategies to realize the slogan of revolutionary literature. Some held the view of "popularization" of literature and some favored language reforms by introducing more Latin words and syntax. As it's known to all, there were continuous arguments and skirmishes, even personal attacks against writers in the other camp since Chinese left-wing literature coming into being. It was complicated to analyze the detailed relationship and specific arguments for they were not the focus in this article. Even worse, some writers wavered in their belief in the civil war and Rectification Movement because of some extremely left policies in Yenan. In 1940s, Ting Ling showed gloomy and nihilistic emotion in her writing, When I Was in Xia Village (1941). Cheng Hsueh-chao was investigated and compelled to write materials to clarify herself again and again because she was born in an upper class family. She wrote in her diary, "I regretted that I could not spend my time and energy on studying a subject, or doing some reading. It was ridiculous doing such checking and confronting.”(Guirong, 2000, pp. 283-84). These phenomena were not revealed by Strong. Or probably Strong chose not to write about. Another possibility was she was too accustomed to observe the revolution itself, which result in her ignorance to the divergence of the inner complexity of Chinese left-wing literature. And her lack of experience also accounted for the ignorance of foreseeing the complex relationship between writers and politics, all her radical experience teaching her understand the fighting function of left-wing literature but not getting along with a peaceful society when communists dominated the country. It was proved Strong was too early to be optimistic in trusting China's communism was perfect. The shortcoming of centralization soon came in the form of Cultural Revolution. Although she had "little actual involvement" with it “in part because of age, in part because of good sense”, (Tracy, 1985, p. 490) she stilled felt restrained in writing and publishing, even seeing her brother Tracy. She had doubts and complaints about China "today", which overturned what she previously thought and she was scared and upset when many of her friends were arrested for the accusation of "anti-party". She felt lonely and depressed all day, which was confirmed by her autobiography writer Tracy B. Strong and Helene Keyssar, "In the end her faith in China, which she had loved far more deeply than she had ever loved Russia, gave place to perhaps bitter doubts and disillusionment.” (Stuart, 1985, p. 519). 


\section{Conclusion}

With the establishment of the anti-Japanese national united front, it was the time that Chinese communists gained its political legitimacy and gradually won increasing support of people. And at the same time, there was overwhelming optimism in America's 1930s that communism would rescue the whole world. For these encouragements, Strong kept wholly glorification of Chinese left-wing literature and writers because they could serve for the revolution. All proved that it was kind of literary construction that persuaded people to expect the beauty and harmony that a communist system would be. With the retreat of radical movement, her illusion was broken. She ignored that any political or social system was on the way to refining and progressing, and every time of her illusion coming into being was due to the spirit in Strong that she was desperate in finding "a faith that was both rational and infallible” (Pringle, 1970, p. 188). Compared with other left-wing writers who turned right, center to be liberals or anti-communists in McCarthy period, Strong was consistently on the left but she was not publicly acknowledged by American communist party.

\section{References}

Aaron, D. (1961). Preface to Writers on the left. New York: Harcourt, Brace\&World, Inc..

Eagleton, T. (1996). Literary theory: An introduction. (2nd ed.) Oxford: Blackwell Publishing.

Guirong, Z. (2000). The memoirs: Cheng Hsueh-chao. Zhengzhou: Henan People’s Publishing House.

Pringle, R. W. (1970). Anna Louise Strong: Propagandist of communism (The doctoral thesis, University of Virginia).

Schram, S. R. (1985). Book review to right in her soul: The life of Anna Louise Strong. The China Quarterly, 103(4), 518-523.

Snow, E. (1983). Living China. Changsha: Hunan People’s Publishing House.

Strong, A. L. (1919, February 4 ). No one knows where. In The seattle union record. Retrieved from http://courses.washington.edu/spcmu/speeches/annalouisestrong.htm

Strong, L. A. (2003). The Chinese conquer China. Beijing: Foreign Language Press.

Strong, L. A. (2006). One-fifth of mankind. New York: Modern Age Books, Inc..

Tracy, B. S., \& Helene K. (1985). Anna Louise Strong: Three interviews with chairman Mao Zedong. The China Quarterly, 103(4), 489-509. 